\title{
Desiccation frequency drives local invasions of non-native gibel carp (Carassius gibelio) in the catchment of a large, shallow lake (Lake Balaton, Hungary)
}

\author{
Árpád Ferincz ${ }^{\mathrm{a}, \mathrm{c}, *}, Z^{2}$ ófia Horváth ${ }^{\mathrm{b}}$, Ádám Staszny ${ }^{\mathrm{c}}$, András Ács ${ }^{\mathrm{d}}$, Nora Kováts ${ }^{\mathrm{a}}$, \\ Csaba F. Vad ${ }^{\mathrm{e}}$, Judit Csaba ${ }^{\mathrm{d}}$, Szandra Sütő ${ }^{\mathrm{a}}$, Gábor Paulovits ${ }^{\mathrm{d}}$ \\ a Department of Limnology, University of Pannonia, Egyetem Str. 10, H-8200 Veszprém, Hungary \\ b WasserCluster Lunz, Dr. Carl Kupelwieser Promenade 5, AT-3293 Lunz am See, Austria \\ c Department of Aquaculture, Szent István University, Páter K. u. 1, H-2100 Gödöllö, Hungary \\ d Balaton Limnological Institute, MTA Centre for Ecological Research, Klebelsberg K. u. 3, H-8237 Tihany, Hungary \\ e Doctoral School of Environmental Sciences, Eötvös Loránd University, Pázmány Péter sétány 1/A, H-1117 Budapest, Hungary
}

\section{A R T I C L E I N F O}

\section{Article history:}

Received 13 November 2014

Received in revised form 12 May 2015

Accepted 15 May 2015

Available online $\mathrm{xxx}$

\section{Keywords:}

Disturbance frequency

Invasive fish

Hydroperiod

Habitat management

Pioneer

\begin{abstract}
A B S T R A C T
Although the problem of non-indigenous species and biological invasions has been widely discussed, knowledge is still limited on their prevention and elimination for the successful management of this problem. In this study, we tested relationships between fish community composition, local environmental parameters and habitat management practice in 11 lentic habitats in the catchment of Lake Balaton (Hungary). The frequency of desiccation events (related to fish pond management) proved to be highly important in increasing the dominance of non-indigenous Carassius gibelio. We suggest that high frequency of desiccation events and the robustness of this species (tolerance to low oxygen levels, gynogenetic reproduction) can contribute to local invasion cycles in wetlands and fish ponds resulting in their continuously high abundance. Our study suggests that ensuring more controlled and stable water level in these habitats can be a successful tool to manage $C$. gibelio invasions.
\end{abstract}

c) 2015 Elsevier B.V. All rights reserved.

\section{Introduction}

Successful biological invasions involve complex interactions between the invading species and the characteristics of the recipient habitats (Hayes and Barry, 2008). It is well-known that certain regions and habitats appear to be particularly vulnerable to invasions (Dudgeon et al., 2006). Certain habitat characteristics are hypothesized to favor successful invasion including (1) environmental similarity between the native and invaded habitats, (2) low to moderate environmental variability, (3) high degree of disturbance, especially of anthropogenic origin, and (4) low richness of native species (Elton, 1958; Lodge, 1993). Recent studies suggest that invasions represent matches and continuous interactions between site characteristics and invaders (Shea and Chesson, 2002). A non-indigenous species is able to displace a native one for two kind of reasons: (1) It has 'a priori' natural pre-adaptations to

* Corresponding author at: Szent István University, Department of Aquaculture, Páter K. u. 1, 2100 Gödöllő, Hungary. Tel.: +36 28522 000/2316.

E-mail address: Ferincz.Arpad@mkk.szie.hu (Á. Ferincz). exploit particular environments. In such cases, invasion is only limited by migration abilities (Allendorf and Lundquist, 2003). (2) If there are no 'a priori' adaptations, some eco-evolutionary changes are needed (Lee, 2002; Lambrinos, 2004). For example, changes in the life history traits (e.g.: age and length at maturity reduction) are often observed in invasive fish populations (Vila-Gispert et al., 2005; Novomenská and Kovác, 2009). Based on the combinations of these two major mechanisms, a migration-based conceptual framework was described: three possible types of invasion scenario were distinguished, as migration change, environmental change and evolutionary change (Facon et al., 2006).

Many non-indigenous species may establish in a single habitat but fail to invade adjacent areas despite having continuous opportunity to migrate and colonize. By examining invasion patterns on regional scale (e.g. catchment scale when dealing with riverine networks), it is possible to determine the driving factors for their success in given habitats, which is crucial to implement management efforts and make predictions for similar systems (Light, 2003). It has long been proposed that increasing intensity or frequency of disturbance facilitates invasions (Elton, 1958; Moyle and Light, 1996; Hierro et al., 2006; Johnson et al., 2008), while recent 
studies indicate that the modification of the original disturbance regime is more important both in terrestrial and freshwater ecosystems (Leprieur et al., 2006; Moret et al., 2006; Clarck and Johnston, 2011). For example, the complex life histories of some fish species (e.g., mixed migratory behaviors) are adaptations to periodic disturbances such as fire and flooding. Thus, introduced species may be able to out-perform native species (Rieman and Clayton, 1997), and the adaptation of natives to a given disturbance frequency, is crucial. In this way, the disruption of natural disturbance regimes will increase the likelihood of successful invasions within a given time frame.

Previous studies investigating the distribution patterns of stream fish communities in the Balaton catchment in Central Europe found the predominant role of local variables in community structure (Sály et al., 2011; Erős et al., 2012). However, Sály et al. (2011) demonstrated that non-indigenous species reduced the descriptive power of local environmental variables. They also suggested that the effect of landscape variables on fish communities depended strongly on the level of disturbance, but the types and level of disturbances were not explicitly addressed.

In our study, we tested whether disturbance frequency (derived from human watershed management) can alter local fish communities in the southern catchment of Lake Balaton, leading to the dominance of non-indigenous fish species. We also aimed at assessing the contribution of human watershed management in comparison to other local environmental parameters on the distribution and abundance of non-indigenous fish species.

\section{Materials and methods}

\subsection{Study area}

Lake Balaton is the largest shallow lake in Central Europe (area: $594 \mathrm{~km}^{2}$, mean depth: $3.2 \mathrm{~m}$ ), with a catchment area of $5775 \mathrm{~km}^{2}$. In the past, the lake was characterized by extreme water level fluctuations (Korponai et al., 2010). Until the 1860s, large wetlands were connected to the southern part of the lake. Afterwards, water level regulation works started by constructing Sió Canal, which reduced the water level of the lake. As a consequence, the connected wetlands mostly disappeared, became astatic or were converted into fish ponds (Korponai et al., 2010; Zlinszky and Tímár, 2013). The shore zone itself has also been drastically altered, by the destruction of the natural ecotone (reed belts) and construction of artificial shore ramparts (e.g. rip-raps). Such changes could have had profound effects on plant and animal communities (Gilvear, 1999).
Before the water level of the lake was regulated and lowered, water cover of the southern wetlands had been relatively stable, though with a fluctuating water level (Zlinszky and Tímár, 2013). Therefore, the Balaton catchment represents a freshwater system with drastically altered hydrological conditions, including disturbance regime, which may have had a considerable role in the invasion of some non-native species (Sály et al., 2011).

The fish fauna of the lake and its inflows were described previously by Paulovits et al. (1994), Erős et al. (2009), Specziár et al. (2009), Sály et al. (2011) and Ferincz et al. (2012), while less is known about the fish fauna of other lentic habitat types like wetlands, recreational ponds and fish ponds in its catchment. Sampling sites were selected to represent the most typical lentic habitat types of the catchment including fish ponds, recreational and angling ponds, reservoirs and wetlands and a characteristic littoral habitat of Lake Balaton as well. Eleven habitats were surveyed in 2011 (Table 1, Fig. 1).

\subsection{Fish sampling}

Electrofishing was carried out seasonally, three times at each site: in spring (April/May), summer (June/July), and autumn (October) of 2011. Sampling was conducted along the same transect in each season near the vegetated shoreline from a small, $12 \mathrm{~V}$ electric motor powered rubber boat using a SAMUS 725MP, $12 \mathrm{~V}$ battery-powered device (used at Pulse DC 380-580 V; $50-70 \mathrm{~Hz}$ ). This method provides reliable information regarding the community structure (Erős et al., 2009; Specziár et al., 2012). The duration of each sampling occasion was $60 \mathrm{~min}$, which meant a transect length mean of $1606 \pm 210 \mathrm{~m}$. Each captured fish was identified to species level, according to the book of Harka and Sallai (2004) and afterwards released, except a randomly selected subsample (30 individuals/sampling) of the non-native gibel (Prussian) carp, which were taken to the laboratory for further study. The 0+ (fry, smaller than app. $15 \mathrm{~mm}$ ) fish were excluded both from field identification and data analysis.

\subsection{Environmental parameters}

Thirteen habitat variables and six habitat management variables were recorded (Table 2). For littoral macrovegetation cover (Reed, Rmace, LOther, see abbreviations in Table 2), percentage ratios of coverage were calculated based on visual estimation for every $50 \mathrm{~m}$ sections of the electrofished transects. In order to calculate percentage ratios, means of sediment characteristics and water depth,

Table 1

General data of the sampling sites.

\begin{tabular}{|c|c|c|c|c|c|}
\hline Waterbody & Site name & GPS coordinates & Site code & Type & Management \\
\hline Töreki pond system & Pond $\mathrm{X}$ & N46 52.886 E18 00.144 & TOR & $\begin{array}{l}\text { Recreational } \\
\text { (angling) pond }\end{array}$ & Intensive stocking \\
\hline Irmapuszta pond system & Pond VII & N46 46.639 E17 44.695 & IRM & Fish pond & $\begin{array}{l}\text { Intensive stocking, } \\
\text { fish farming }\end{array}$ \\
\hline Öszöd marsh & & N46 49.120 E17 48.219 & OSZ & Wetland & $\begin{array}{l}\text { None, water level } \\
\text { control }\end{array}$ \\
\hline Lake Balaton & Sajkod & N46 54.972 E17 50.289 & BAL & Shallow lake & $\begin{array}{l}\text { Commercial } \\
\text { fishing, angling }\end{array}$ \\
\hline Kis-Balaton Water Protection System & Reservoir II inlet & N46 38.601 E17 11.301 & ING & Reservoir & None \\
\hline Kis-Balaton Water Protection System & Reservoir I Inlet & N46 39.589 E17 07.632 & POG & Reservoir & $\begin{array}{l}\text { Commercial } \\
\text { fishing, angling }\end{array}$ \\
\hline Kis-Balaton Water Protection System & Reservoir I Turn & N46 36.444 E17 09.519 & RAD & Reservoir & Commercial fishing \\
\hline Kis-Balaton Water Protection System & Reservoir I, outflow & N46 37.722 E17 09.398 & KAN & Reservoir & $\begin{array}{l}\text { Commercial } \\
\text { fishing, angling }\end{array}$ \\
\hline Kis-Balaton Water Protection System & Connencting channel & N46 38.178 E17 10.861 & $4 \mathrm{TA}$ & Channel & None \\
\hline Csombárdi pond & & N46 26.890 E17 39.440 & CSO & $\begin{array}{l}\text { Abandoned fish } \\
\text { pond (since 2008) }\end{array}$ & None \\
\hline Gyótapuszta Pond System & Pond II & N46 32.229 E17 27.071 & GYO & $\begin{array}{l}\text { Abandoned fish } \\
\text { pond (since 2002) }\end{array}$ & None \\
\hline
\end{tabular}




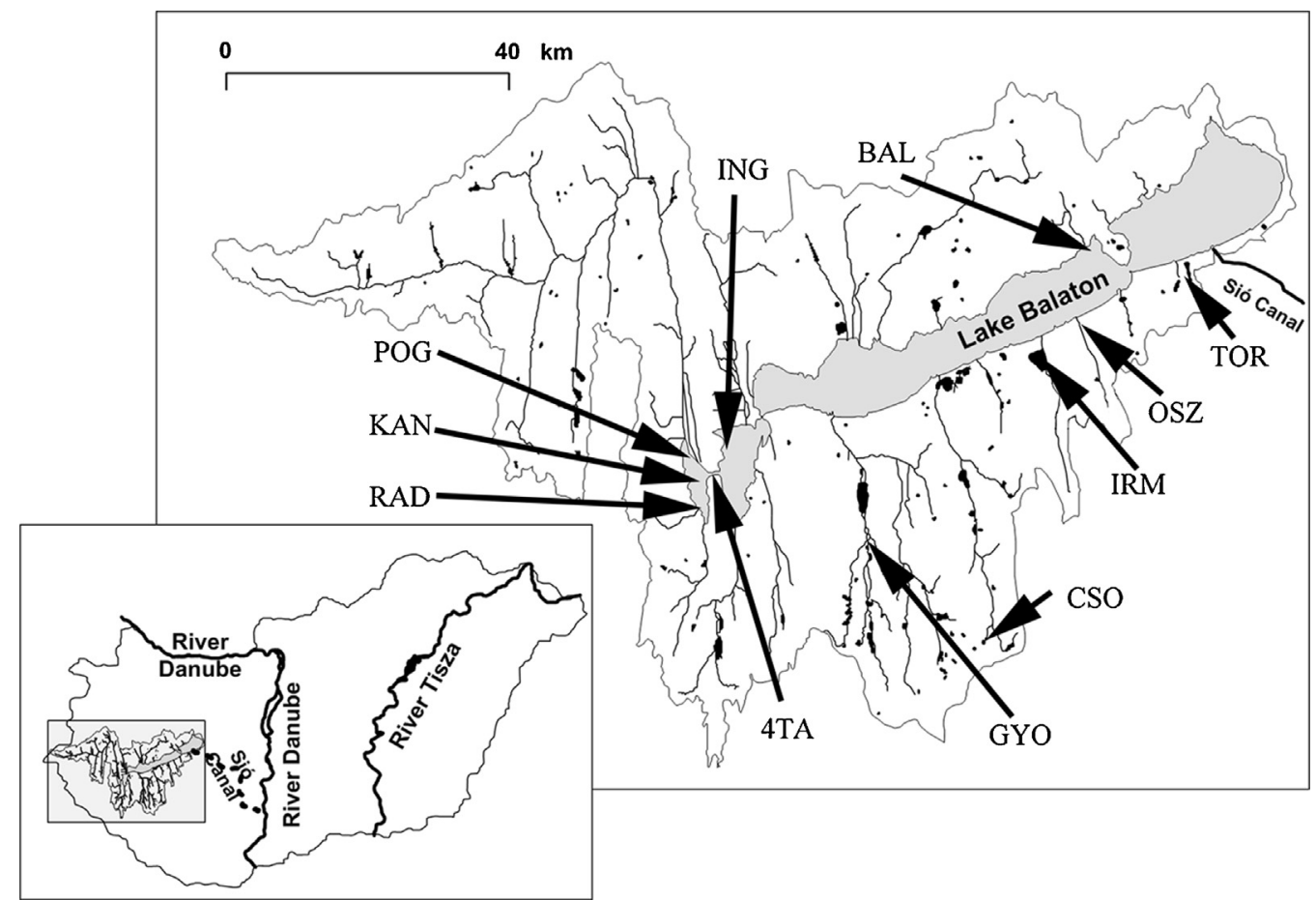

Fig. 1. Map of the Balaton catchment with the sampling sites (See abbreviations in Table 1).

these variables were recorded at 10 randomly selected points close to the transects. These measurements were conducted once, during the summer sampling, when macrovegetation is fully developed. A HORIBA U-10 water quality checker was used to measure turbidity, conductivity and $\mathrm{pH}$ at each sampling occasion, mean values were used during the analyses. Surface area and data on habitat management variables were gathered from digitalized topographical maps using GIS software or from literature sources (Dövényi, 2010; VKKI, 2010). The watersheds managers (staff of the national park directorates) were interviewed mainly for the assessment of the occurrence of desiccation events.

\subsection{Data analysis}

Redundancy analysis (RDA) with an automatic forward selection procedure was applied to explore variables explaining a significant share of the non-indigenous species distribution and abundance. In this process, an unconstrained Principal Component Analysis on the species-habitat datasets was followed by the passive projection of the explanatory variables. The number of permutations in MonteCarlo simulation were set to 1000 . In the first model, we used binary (presence-absence) data of species (without any weighting) occurring at least two sites with all the environmental variables

Table 2

List of the environmental variables used in the RDAs and variance partitioning (all habitat characteristic data were $\log (x+1)$ transformed).

\begin{tabular}{|c|c|c|c|c|}
\hline & Name & Abbreviation & Measure & Mean \pm SD \\
\hline \multirow{13}{*}{$\begin{array}{l}\text { Habitat characteristics } \\
\text { (Local effects) }\end{array}$} & Reed (Phragmites communis) & Reed & Shoreline coverage (\%) & $58.46 \pm 27.69$ \\
\hline & Reed-mace (Typha sp.) & Rmace & Shoreline coverage (\%) & $29.76 \pm 26.03$ \\
\hline & $\begin{array}{l}\text { Other macrophytes in the littoral } \\
\text { zone (eg.: Carex sp., Juncus sp.) }\end{array}$ & LOther & Shoreline coverage (\%) & $9.61 \pm 13.65$ \\
\hline & $\begin{array}{l}\text { Submerse macrophytes } \\
\text { (Potamogeton sp., Myriophillum sp., } \\
\text { Ceratophyllum sp.) }\end{array}$ & Smerse & Coverage (\%) & $27.07 \pm 28.85$ \\
\hline & Area & Area & $\mathrm{km}^{2}$ & $52.06 \pm 156.7$ \\
\hline & Silt & Silt & Bottom coverage (\%) & $62.3 \pm 30.92$ \\
\hline & Sand & Sand & Bottom coverage (\%) & $18.46 \pm 21.07$ \\
\hline & Gravel & Gravel & Bottom coverage (\%) & $10.38 \pm 18.24$ \\
\hline & Clay & Clay & Bottom coverage (\%) & $8.84 \pm 11.46$ \\
\hline & Turbidity & Turbid & NTU & $117 \pm 118.7$ \\
\hline & Conductivity & Cond & $\mu \mathrm{S} / \mathrm{cm}$ & $703.38 \pm 136.3$ \\
\hline & $\mathrm{pH}$ & $\mathrm{pH}$ & & $8.41 \pm 0.41$ \\
\hline & Average depth & Depth & $\mathrm{cm}$ & $105.38 \pm 44.99$ \\
\hline \multirow{6}{*}{$\begin{array}{l}\text { Habitat management } \\
\text { characteristics }\end{array}$} & Activity of commercial fisheries & Fishing & binary data & $36.3 \%$ of answer yes \\
\hline & Water level managed by suction & Suction & & $9 \%$ of answer yes \\
\hline & $\begin{array}{l}\text { Water supply from } \\
\text { inflow/tributary }\end{array}$ & Inflow & & $81.8 \%$ of answer yes \\
\hline & $\begin{array}{l}\text { Watershed dried out at least once } \\
\text { in the last } 10 \text { years }\end{array}$ & Drought & & $27.3 \%$ of answer yes \\
\hline & Human constructed habitat & Constructed & & $72.7 \%$ of answer yes \\
\hline & Protected habitat & Protected & & $81.8 \%$ of answer yes \\
\hline
\end{tabular}




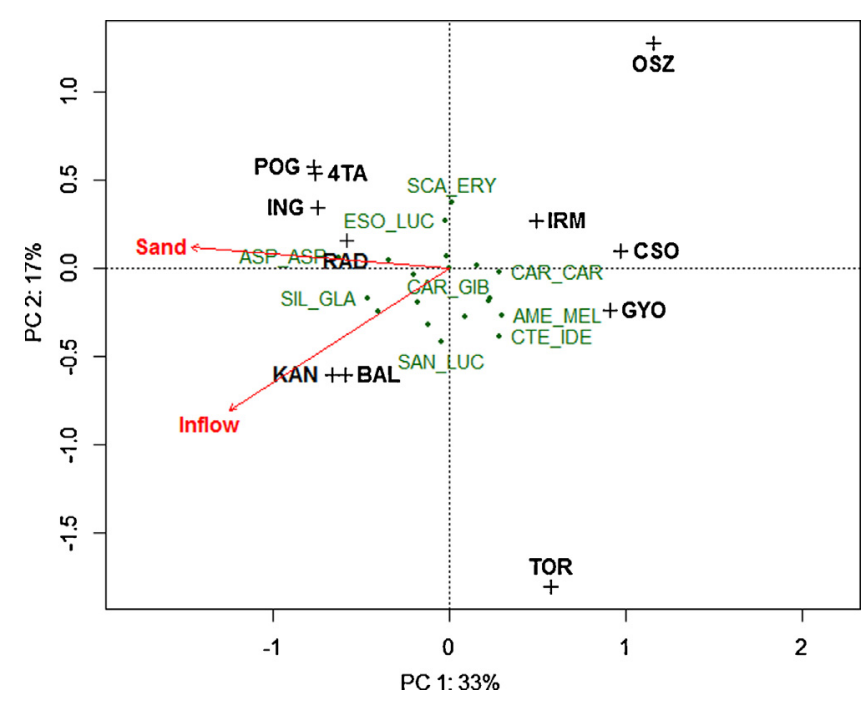

Fig. 2. RDA model for presence-absence data. Red arrows represent the significant environmental variables, species are indicated with green and habitats with black labels. (For interpretation of the references to color in this figure legend, the reader is referred to the web version of this article.)

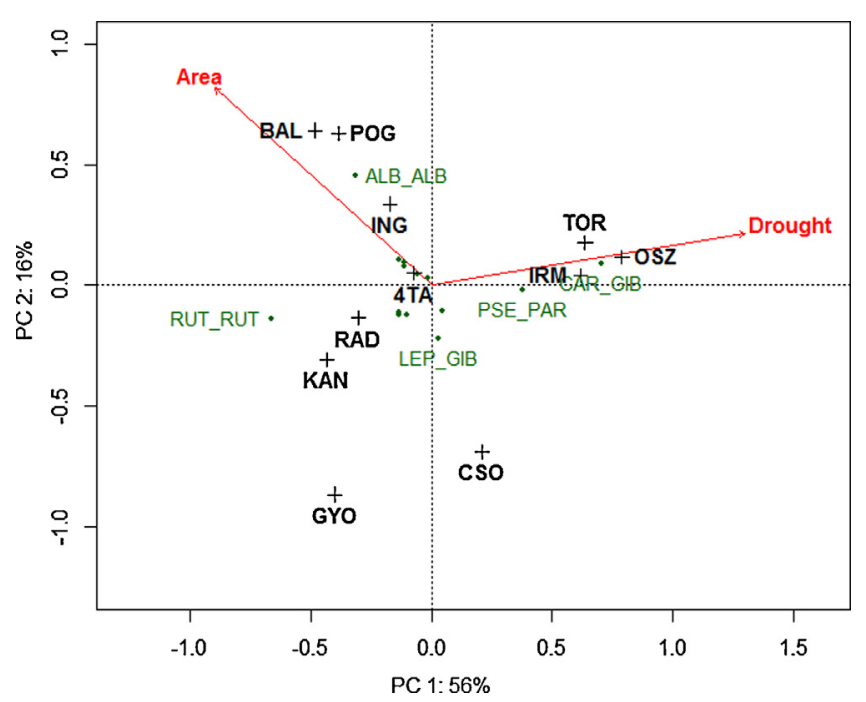

Fig. 3. RDA model for the fish assemblage based on Relative Abundance data. Red arrows represent significant environmental variables, species are indicated with green and habitats with black labels. (For interpretation of the references to color in this figure legend, the reader is referred to the web version of this article.) listed in Table 1. As forward selection revealed significant effects both among the 'habitat characteristics' and 'habitat management' variable groups, variance partitioning was used to assess the relative contribution of the different variable groups (Borcard et al., 1992). A second RDA model was constructed for arcsine-squareroot-transformed relative abundance data (i.e.: the ratio between the number of individuals of a given species and the the total number of fish caught in each habitat) of dominant species (reaching $5 \%$ of relative abundance at least 1 site) using the same procedure. Mean data of the three sampling occasions were used in order to improve the robustness of the results. All analyses were made in $\mathrm{R}$ software (R Development Core Team, 2013), with the package "packfor" (Dray et al., 2013) and "vegan" (Oksanen et al., 2013).

\section{Results}

\subsection{Fish communities}

The total number of individuals caught was $N=8899$. Twentytwo fish species were identified at the 11 sampling sites, of which 10 (34.5\%) were non-indigenous (Table 3). At least 1 non-native species was recorded at each sampling site, with the lowest number $(n=1)$ in Pogányvári-víz (POG), and with the highest number $(n=6)$ in the Töreki-fishpond (TOR). The non-indigenous gibel carp (Carassius gibelio Bloch, 1782) was present at every sampling site. It was the most abundant and, at the same time, the most frequent member of the fish fauna. It constituted $34.21 \%$ of all the fish individuals caught (3044 individuals).

\subsection{Effects of environmental and habitat management variables on the fish community}

The first two axes of the RDA model accounted for $50 \%$ of the total variance in the presence-absence data (Fig. 2). Forward selection resulted in two significant explanatory variables: 'presence of inflow' from habitat management group, and 'ratio of sandy bottom' from the local environmental characteristics group (Table 4).

Two groups of habitats could be separated along the first axis of the RDA triplot, determined by the significant explanatory variables and species composition: semi-natural habitats with relatively high number of native and low number of non-native species (BAL, POG, KAN, RAD, ING, 4TA). The second group was formed by fish ponds and wetland with relatively low number of native species and high number of non-natives (IRM, TOR, CSO, GYO, OSZ). Significant environmental factors were positively related to the first group and negatively to the second.

The first two axes of the RDA model constructed for the arcsinesquare-root-transformed relative abundance data accounted for $72 \%$ of the total variance (Fig. 3 ). The forward selection identified two significant environmental variables: 'area' from the 'local environmental variables' and 'occurrence of dry-out' from the 'habitat management' group (Table 5).

Most of the species were associated with the centroid, therefore not labeled on the RDA triplot, while Rutilus rutilus (Linnaeus, 1758), Alburnus alburnus (Linnaeus 1758), Psudorasbora parva (Temminck and Schlegel 1846) and $C$. gibelio were clearly separated. These species proved to be dominant in different habitat types (Fig. 3). Regarding non-natives, one group of habitats (TOR, IRM, OSZ; two fish ponds and a wetland) was associated strongly with the two dominant non-native species ( $P$. parva, C. gibelio). The other habitats were mostly characterized by semi-natural fish fauna, differing in the dominant species, which was either A. alburnus (BAL, POG, ING) or $R$. rutilus (KAN, RAD, GYO). A group of transitionary habitats (4TA, CSO) was also visible.

The factor responsible for the separation of the habitat group dominated by non-native species was the effect of desiccation occurrence. The semi-natural group of habitats differed according to their 'area': habitats with the dominace of $A$. alburnus showed a positive relationship with 'area'.

The significantly explained variance of the RDA model constructed for presence-absence data proved to be $34 \%$ in total. Pure environmental [Env: 'ratio of sandy bottom'] and pure habitat management variables [Use: 'presence of inflow'] accounted for $12 \%$ and $11 \%$ of the variability, and $1 \%$ of shared effects was detectable. The RDA model for relative abundance data explained 50\% variance in total. Pure environmental [Env: 'area'], shared environmental, habitat use [EnvxUse] and pure habitat use [Use: 'occurrence of drying-out'] variables accounted for $9 \%, 12 \%$ and $29 \%$. 
Table 3

Species composition, relative abundance and diversity of the examined habitats.

\begin{tabular}{|c|c|c|c|c|c|c|c|c|c|c|c|c|c|c|}
\hline \multicolumn{3}{|l|}{ Species } & \multicolumn{11}{|c|}{ Sampling site } & \multirow[t]{2}{*}{ Status } \\
\hline Scientific name & Common name & Abbreviation & RAD & POG & KAN & $4 \mathrm{TA}$ & ING & OSZ & BAL & CSO & GYO & IRM & TOR & \\
\hline Rutilus rutilus & Roach & RUT_RUT & 59.29 & 35.85 & 76.86 & 29.86 & 28.48 & 0 & 21.52 & 9.20 & 41.16 & 0.07 & 0.08 & Native \\
\hline Carassius gibelio & Gibel carp & CAR_GIB & 18.18 & 8.96 & 8.42 & 28.98 & 21.69 & 93.14 & 0.66 & 26.71 & 0.47 & 47.30 & 64.06 & Alien \\
\hline Lepomis gibbosus & Pumpkinseed & LEP_GIB & 0.26 & 0 & 1.82 & 0 & 2.32 & 0.29 & 0.22 & 29.38 & 3.95 & 0.87 & 0.59 & Alien \\
\hline Cyprinus carpio & Common carp & CYP_CAR & 1.32 & 2.12 & 2.24 & 0.71 & 6.29 & 0 & 3.36 & 0.89 & 3.26 & 7.46 & 5.46 & Native \\
\hline Perca fluviatilis & Perch & PER_FLU & 1.84 & 1.18 & 3.51 & 0.18 & 1.49 & 0 & 4.16 & 10.98 & 4.88 & 0 & 0 & Native \\
\hline Abramis brama & Bream & ABR_BRA & 1.58 & 2.83 & 0.70 & 6.54 & 7.95 & 0.00 & 0.95 & 0 & 0.47 & 0 & 0.17 & Native \\
\hline Leuciscus aspius & Asp & ASP_ASP & 3.56 & 7.55 & 0.56 & 1.24 & 1.66 & 0.00 & 0.36 & 0 & 0 & 0 & 0 & Native \\
\hline Silurus glanis & Wels & SIL_GLA & 0.40 & 0.24 & 1.40 & 2.12 & 5.30 & 0 & 0.22 & 0 & 0 & 0.07 & 0.08 & Native \\
\hline Blicca bjoerkna & White bream & BLI_BJO & 7.91 & 4.72 & 0.28 & 11.13 & 3.81 & 0 & 1.60 & 0 & 0 & 0 & 0 & Native \\
\hline Alburnus alburnus & Bleak & ALB_ALB & 1.58 & 33.73 & 2.81 & 2.47 & 17.38 & 0 & 56.60 & 0 & 0 & 0.33 & 1.60 & Native \\
\hline Scardinius erythrophthalmus & Rudd & SCA_ERY & 2.24 & 2.12 & 0 & 13.07 & 0.99 & 0.49 & 3.43 & 10.39 & 11.86 & 0.13 & 0 & Native \\
\hline Tinca tinca & Tench & TIN_TIN & 0.26 & 0 & 0 & 0 & 0 & 1.49 & 0.22 & 0 & 1.86 & 0 & 0.17 & Native \\
\hline Sander lucioperca & Pikeperch & SAN_LUC & 1.32 & 0 & 0.70 & 0 & 0 & 0 & 0.73 & 2.97 & 0 & 0 & 0.50 & Native \\
\hline Gymnocephalus cernua & Ruffe & GYM_CER & 0.13 & 0 & 0 & 0 & 0 & 0 & 0 & 0 & 0 & 0.07 & 0 & Native \\
\hline Esox lucius & Pike & ESO_LUC & 0.13 & 0 & 0 & 1.24 & 0.50 & 2.43 & 0.44 & 0 & 2.33 & 0.67 & 0 & Native \\
\hline Pseudorasbora parva & Topmouth gudgeon & PSE_PAR & 0 & 0 & 0.56 & 2.12 & 0.99 & 2.16 & 0 & 8.61 & 0 & 42.70 & 23.26 & Alien \\
\hline Rhodeus amarus & Bitterling & RHO_SER & 0 & 0 & 0.14 & 0.35 & 0.66 & 0 & 5.32 & 0 & 25.58 & 0.27 & 0.08 & Protected \\
\hline Neogobius fluviatilis & Monkey goby & NEO_FLU & 0 & 0 & 0 & 0 & 0.50 & 0 & 0.07 & 0 & 0 & 0 & 0 & Alien \\
\hline Ctenopharyngogon idella & Grass carp & CTE_IDE & 0 & 0 & 0 & 0 & 0 & 0 & 0.15 & 0.59 & 0.70 & 0 & 0.76 & Alien \\
\hline Carassius carassius & Crucian carp & CAR_CAR & 0 & 0 & 0 & 0 & 0 & 0 & 0 & 0.30 & 1.63 & 0 & 0 & Native \\
\hline Ameiurus melas & Black bullhead & AME_MEL & 0 & 0 & 0 & 0 & 0 & 0 & 0 & 0 & 1.86 & 0.07 & 0.42 & Alien \\
\hline Hypophthalmichthys molitrix & Silver carp & HYP_MOL & $\mathbf{0}$ & 0 & 0 & 0 & 0 & 0 & 0 & 0 & 0 & 0 & 2.77 & Alien \\
\hline Number of species & 15 & 10 & 13 & 13 & 15 & 6 & 17 & 10 & 13 & 12 & 14 & & & \\
\hline Shannon diversity & 1.414 & 1.625 & 1.000 & 1.837 & 2.023 & 0.297 & 1.444 & 1.815 & 1.741 & 1.049 & 1.105 & & & \\
\hline Number of Individuals & 759 & 421 & 713 & 567 & 601 & 1009 & 1370 & 337 & 430 & 1501 & 1191 & & & \\
\hline
\end{tabular}


Table 4

Significant environmental variables resulted from the forward selection procedure (presence-absence data).

\begin{tabular}{|c|c|c|c|c|}
\hline Variable group & Significant variable & $R^{2}$ & $F$ value & $P$ value \\
\hline Habitat characteristics & Sand & 0.219 & 2.518 & 0.022 \\
\hline Habitat management & Inflow & 0.176 & 2.329 & 0.027 \\
\hline
\end{tabular}

Table 5

Significant environmental variables resulted from the forward selection procedure (relative abundance data).

\begin{tabular}{|c|c|c|c|c|}
\hline Variable group & Significant variable & $R^{2}$ & $F$ value & $P$ value \\
\hline Habitat characteristics & Area & 0.132 & 2.638 & 0.015 \\
\hline Habitat management & Drought & 0.469 & 7.934 & 0.005 \\
\hline
\end{tabular}

\section{Discussion}

\subsection{Community structure}

Two main groups could be differentiated according to their species composition. Fish ponds and wetlands (IRM, TOR, OSZ) were characterized by the highest abundances of non-natives, while reservoirs (POG, KAN, ING, RAD) and the lake itself (BAL) hosted more natural fauna. The latter group was strongly associated with the presence of inflow, which might affect the number of native species and diversity positively by maintaining higher connectivity with other local populations. The spawning migration of native species (e.g. R. rutilus, Blicca bjoerkna (Linnaeus, 1758), Abramis brama (Linnaeus, 1758)) to the tributaries could help maintain a stronger population of these fishes (Hladík and Kubecka, 2003).

We found that fish ponds hosted a high number of non-native species which often dominated the communities. The relationship of fish ponds and non-native species has a long history. The most typical reasons for introduction and therefore, pathways for a nonnative fish is aquaculture or fish farming and intentional releases of ornamental fish (e.g. Hickley and Chare, 2004; Copp et al., 2005, 2010; Gozlan et al., 2010). C. gibelio was originally imported to Hungary in 1954 for fish farming purposes (Szalay, 1954), and numerous similar examples of other species from all over the word could be mentioned (e.g.: Naylor et al., 2005; Casal, 2006). These populations can afterwards act as potential source of invasions. Fish ponds of the Balaton catchment were previously assumed to be the major sources of non-native species as high abundance of nonindigenous species, especially $C$. gibelio and $P$. parva, were found in the neighboring, connected sections of small watercourses (Sály et al., 2011; Erös et al., 2012, 2014). Area covered by fish ponds in the catchment of the investigated stream segments was found to be the most important human disturbance variable, being positively associated with the abundance of non-native species in the surveyed streams. Therefore, the authors formulated the 'polluting ponds' hypothesis regarding their role in the spread on invasives (Erős et al., 2012). But this has not been explicitly tested by studying the communities of fish ponds of the Balaton catchment. More evidence on the high persistence of $C$. gibelio and $P$. parva in aquaculture systems and especially in their water-supply canals were provided from South Moravia region of the Czech Republic (Musil et al., 2007). According to our presence-absence data, some non-natives were amongst the most frequent fish species, occurring at every $(C$. gibelio) or almost every (P. parva, Lepomis gibbosus (Linnaeus, 1758)) site. On the other hand, the analysis of relative abundance data gave some evidence for the 'polluting pond' hypothesis (sensu Erös et al., 2012). The high relative abundance of $C$. gibelio in fish ponds (TOR, IRM) definitely supported the theory that high amounts of nonnative species might escape from these habitats and contribute to the degradation of natural waters in the catchment.

Reservoirs often suffer from human disturbance, such as extreme water level fluctuations or unnatural water regimes, therefore their invasion facilitating role has been demonstrated worldwide (e.g. Moyle and Light, 1996; Clavero and Hermoso, 2011; Tarkan et al., 2012a). Our results, however, were contrary to this theory: the surveyed reservoir (sites ING, POG, RAD, KAN) and shallow lake (BAL) habitats were dominated by native fish species. The management history of these sites may provide explanation for this finding. The surveyed reservoirs are parts of the Kis-Balaton Water Protection system and were inundated more than 20 years ago, since when no notable human disturbance (e.g. fish stocking, heavy water level fluctuations) occurred, allowing natural succession processes to operate. After inundation, a rapid invasion of gibel carp was observed. Its colonization was possible naturally, via tributaries of the reservoirs. After 10 years since inundation, its population in the reservoirs declined and stabilized, most likely due to the lower eutrophication tolerance of gynogenetic form. This reproductive characteristic seemed to be effective in the initial, colonization phase of reservoir fish community development. Later on, the stressful hyperthrophic environment and the increasing abundance of native competitors are possible drivers towards sexual reproduction and result in lower gibel carp abundance (see details in: Paulovits et al., 2014).

The difference in fish community between intensively (productive; TOR, IRM) and the extensively (non-productive; CSO, GYO) managed fish ponds was also visible. There was no fish harvesting associated drainage in the latter ponds and they were characterized by semi-natural (GYO) or transitional (CSO) fish fauna, in line with the time since they had been abandoned (Table 1). This finding also supports the theory, that the long-term constant water cover might be unfavorable for gibel carp.

\subsection{Role of environmental characteristics and habitat management in gibel carp distribution}

We found that regular desiccation (or drainage, associated with fish harvesting in fish ponds) can be a major driver of fish community structure. This variable accounted for most of the significant variance in explaining differences in dominance patterns, and no other variable showed a significant relationship with the relative abundance of the species. Management (Use) variables, including desiccation have more powerful effects on relative abundances than on presence-absence. This means that even though the introductions were not inhibited, suitable management may still be able to help suppress the abundance of non-natives in a near-natural state.

We assume that a series of local invasion events occurred in the fish ponds and the wetland which were mediated by periodical (5-10 years) drying-outs. Drainage results in the elimination of the majority of the inhabiting fish. After re-flooding, the fish community structure is species poor and strongly asymmetric, which may be regarded as an early successional phase. It should be noted, however, that the desiccation of a waterbody does not necessarily result in the complete extinction of the local fish fauna. Usually, 
some refugia can be found, (e.g. a deeper hole in the lake bed, or the inflow itself), which allows the survival of a small portion of fish. As C. gibelio have an effective oxygen deficiency tolerance mechanism (Lutz and Nilsson, 1994), it can successfully cope with such unfavorable periods (Liasko et al., 2011). After the reflooding of the habitat, the alternative gynogenetic reproduction mechanism of the species (Kalous and Knytl, 2011; Tarkan et al., 2012b) provides an advantage during re-colonization over other species and results in large monodominant communities. At all human-mediated drainage events disrupt natural succession and this maintains pioneer communities over time, dominated by gibel carp.

The dominance of $C$. gibelio at early successional stages was previously found in other habitats of the Balaton catchment (Ferincz et al., 2012; Paulovits et al., 2014). The drastic changes in the hydroperiod length of originally permanent waterbodies (Zlinszky and Tímár, 2013), can be interpreted as disturbances and fit well into the 'environmental change' type invasion scenario in the conceptual framework described by Facon et al. (2006). Fish communities of wetland areas of the Balaton catchment are not adapted for such events and therefore, this process is an alteration of the natural disturbance regime, which generally facilitates invasions (Moret et al., 2006; Clarck and Johnston, 2011). This scenario is similar in fish ponds, where desiccation occurs in 1-5 year periods associated with fish harvesting. Small-bodied individuals of nonnative fish might find refuge in the lake bed or in draining channels until refilling. Moreover, the juveniles of non-natives are stocked accidentally in numerous cases (e.g. Rylková et al., 2013). In the case of wetlands, this process will likely be facilitated by global climate change, since longer dry periods have been predicted for the region (Krüzselyi et al., 2011).

\subsection{Role of local invasions on catchment level and management opportunities}

Local invasions are probably the main drivers of the source-sink dynamics of non-native species on the catchment level (Erős et al., 2012). Fish ponds, angling ponds and wetlands are source populations of non-natives (mainly $C$. gibelio and $P$. parva), providing continuous pressure for the streams and other semi-natural habitats of the system. Such dynamics were also reported not only in human-modified and non-native-stressed habitats (Woodford and McIntosh, 2010; Glowaczki and Penczak, 2013), but also in case of a beaver-influenced natural landscape (Schlosser, 1998).

The management possibilities on non-native fish invasions are very limited (Britton et al., 2010). The complete eradication (by piscicides or removal) are obviously impossible, as the methods impose substantial collateral damage on native species and need huge effort (Simberloff, 2002; Koehn, 2004). As our study revealed the role of a management related disturbance factor (occurrence of drying-out), this implies the opportunity to control individual invasion events simply by providing continuous water cover in wetlands, and by alternative management (more precise eradication of 'junk' fishes from the draining channels and fish beds) of fish ponds. These implications might result in not only the decline of $C$. gibelio in the studied habitats, but simultaneously in adjoining streams.

\section{Acknowledgements}

The research of Árpád Ferincz was supported by the European Union and the State of Hungary, co-financed by the European Social Fund in the framework of TÁMOP 4.2.4. A/2-11-1-2012-0001 'National Excellence Program'. Field work was supported by the project TÁMOP-4.2.2.A-11/1/KONV-2012-0064. Ádám Staszny was supported by Research Centre of Excellence-9878/2015/FEKUT. The authors are grateful to the three anonymous reviewers, whose comments were essential to improve the quality of the manuscript and Dr. Robin Welcomme for English corrections.

\section{References}

Allendorf, F.W., Lundquist, L.L., 2003. Introduction: population biology, evolution, and control of invasive species. Conserv. Biol. 17, 24-30.

Britton, J.R., Gozlan, R.E., Copp, G.H., 2010. Managing non-native fish in the environment. Fish Fish. 12, 256-274

Borcard, D., Legendre, P., Drapeau, P., 1992. Partialling out the spatial component of ecological variation. Ecology 73, 1045-1055.

Casal, C.M.V., 2006. Global documentation of fish introductions: the growing crisis and recommendations for action. Biol. Invasions 8, 3-11.

Clarck, G.F., Johnston, E.L., 2011. Temporal change in the diversity-invasibility relationship in the presence of a disturbance regime. Ecol. Lett. 14, 52-57.

Clavero, M., Hermoso, V., 2011. Reservoirs promote the taxonomic homogenization of fish communities within river basins. Biodiv. Conserv. 20, 41-57.

Copp, G.H., Bianco, P.G., Bogutskaya, N.G., Erős, T., Falka, I., Ferreira, M.T., Fox, M.G., Freyhof, J., Gozlan, R.E., Grabowska, J., Kováč, V., Moreno-Amich, R., Naseka, A.M. Peňáz, M., Povž, M., Przybylski, M., Robillard, M., Rusell, I.C., Stakenas, S., Šumer S., Vila-Gispert, A., Wiesner, C., 2005. To be or not to be, a non-native freshwater fish? J. Appl. Ichthyol. 21, 242-262.

Copp, G.H., Tarkan, A.S., Godard, M.J., Edmonds, N.J., Wesley, K.J., 2010. Preliminary assessment of feral goldfish impacts on ponds, with particular reference to native Crucian carp. Aquat. Invasions. 5, 413-422.

Dövényi, Z., 2010. Magyarország kistájainak katasztere, Második, átdolgozott és bővített kiadás. MTA Földrajztudományi Kutatóintézet, Budapest, pp. 876 p (in Hungarian)

Dray, S., Legendre, P., Blanchet, G., 2013. packfor: Forward Selection with Permutation (Canoco p.46). R Package Version 0.0-8/r109. http://R-Forge.R-project.org/ projects/sedar/

Dudgeon, D., Arthington, A.H., Gessner, M.O., Kabawata, Z.I., Knowler, D.J., Leveque, C., Naiman, R.J., Prieur-Richard, A.H., Sota, D., Stiasszny, M., Sulliavan, C.A., 2006. Freshwater biodiversity: importance, threats, status and conservation challenges. Biol. Rev. 81, 163-182.

Elton, C.S., 1958. The Ecology of Invasions by Animals and Plants. Methuen and Co. Ltd, London.

Erős, T., Sály, P., Takács, P., Higgins, C.L., Bíró, P., Schmera, D., 2014. Quantifying temporal variability in the metacommunity structure of stream fishes: the influence of non-native species and environmental drivers. Hydrobiologia 722, 31-43.

Erős, T., Sály, P., Takács, P., Specziár, A., Bíró, P., 2012. Temporal variability in the spatial and environmental determinants of functional metacommunity organization-stream fish in a human-modified landscape. Freshw. Biol. 57, 1914-1928.

Erős, T., Specziár, A., Bíró, P., 2009. Assessing fish assemblages in reed habitats of a large shallow lake-a comparison between gillnetting and electric fishing. Fish. Res. 96, 70-76.

Facon, B., Genton, B.J., Shykoff, J., Jarne, P., Estoup, A., David, P., 2006. A general ecoevolutionary framework for understanding bioinvasions. Trends Ecol. Evol. 21, $130-135$.

Ferincz, Á., Staszny, Á., Ács, A., Weiperth, A., Tátrai, I., Paulovits, G., 2012. Long-term development of fish assemblage in Lake Fenéki (Kis-Balaton Water Protection System Hungary): succession, invasion and stabilization. Acta Zool. Sci. Acad. Hung. 58 (Suppl. 1), 3-18.

Gilvear, D.J., 1999. Fluvial geomorphology and river engineering: future roles utilizing a fluvial hydrosystems framework. Geomorphology 31, 229-245.

Glowaczki, L.B., Penczak, T., 2013. Drivers of fish diversity, homogenization/differentiation and species range expansions at the watershed scale. Diversity Distrib. 19, 907-918.

Gozlan, R.E., Britton, J.R., Cowx, I., Copp, G.H., 2010. Current knowledge on non-native freshwater fish introductions. J. Fish Biol. 76, 751-786.

Harka, Á., Sallai, Z., 2004. Magyarország halfaunája. Nimfea Természetvédelmi Egyesület, Szarvas (269 pp.; in Hungarian).

Hayes, K.R., Barry, S.C., 2008. Are there any consistent predictors of invasion success? Biol. Invasions 10, 483-506.

Hickley, P., Chare, S., 2004. Fisheries for non-native species in England and Wales: angling or the environment? Fish. Manage. Ecol. 11, 203-212.

Hierro, J.L., Villarreal, D., Eren, O., Graham, J.M., Callaway, R.M., 2006. Disturbance facilitates invasion: the effects are stronger abroad than at home. Am. Nat. 168, $144-156$.

Hladík, M., Kubecka, J., 2003. Fish migration between a temperate reservoir and its main tributary. Hydrobiologia 504, 251-266.

Johnson, P.T.J., Olden, J.D., Vander Zanden, M.J., 2008. Dam invaders: impoundments facilitate biological invasions into freshwaters. Front. Ecol. Environ. 6, 357-363.

Kalous, L., Knytl, M., 2011. Karyotype diversity of the offspring resulting from reproduction experiment between diploid male and triploid female of silver Prussian carp, Carassius gibelio (Cyprinidae Actinopterygii). Folia Zool. 60, 115-121.

Koehn, J.D., 2004. Carp (Cyprinus carpio) as a powerful invader of Australian waterways. Freshw. Biol. 49, 882-894.

Korponai, J., Braun, M., Buczkó, K., Gyulai, I., Forró, L., Nédli, J., Papp, I., 2010. Transition from shallow lake to a wetland: a multi-proxy case study in Zalavári Pond, Lake Balaton, Hungary. Hydrobiologia 641., 225-244. 
Krüzselyi, I., Bartholy, J., Horányi, A., Pieczka, I., Pongrácz, R., Szabó, P., Szépszó, G. Torma, Cs., 2011. The future climate characteristics of the Carpathian Basin based on a regional climate model mini-ensemble. Adv. Sci. Res. 6, 69-73.

Lambrinos, J.G., 2004. How interactions between ecology and evolution influence contemporary invasion dynamics. Ecology 85, 2061-2070.

Lee, C.E., 2002. Evolutionary genetics of invasive species. Trends Ecol. Evol. 17, 386-391.

Leprieur, F., Hickey, M.A., Arbuckle, C.J., Closs, G.P., Brosse, S., Townsend, C.R., 2006. Hydrological disturbance benefits a native fish at the expense of an exotic fish. J. Appl. Ecol. 43, 930-939.

Liasko, R., Koulish, A., Pogrebniak, A., Papiggioti, O., Taranenko, L., Leonardos, I., 2011. Influence of environmental parameters on growth pattern and population structure of Carassius auratus gibelio in Eastern Ukraine. Hydrobiologia 658, 317-328.

Light, T., 2003. Success and failure in a lotic crayfish invasion: the roles of hydrologic variability and habitat alteration. Freshw. Biol. 48, 1886-1897.

Lodge, D.M., 1993. Biological invasions: lessons for ecology. Trends Ecol. Evol. 8, 133-136.

Lutz, P.L., Nilsson, G.E., 1994. The Brain Without Oxygen, Causes of Failure and Mechanisms for Survival. R.G. Landes Company, Austin, TX, pp. 49-63.

Moret, T.J., Snyder, J.D., Collins, J.P., 2006. Altered drying regime controls distribution of endangered salamanders and introduced predators. Biol. Conserv. 127, $129-138$.

Moyle, P.B., Light, T., 1996. Biological invasions of fresh water: general rules and assembly theory. Biol. Conserv. 78, 149-161.

Musil, J., Adámek, Z., Baranyi, C., 2007. Seasonal dynamics of fish assemblage in a pond canal. Aquacult. Int. 15, 217-226.

Naylor, R., Hindar, K., Fleming, I.A., Goldburg, R., Williams, S., Volpe, J., Whoriskey, F., Eagle, J., Kelso, D., Mangel, M., 2005. Fugitive Salmon: assessing the risks of escaped fish from Net-Pen Aquaculture. BioScience 55, 427-437.

Novomenská, A., Kovác, V., 2009. Life-history traits of non-native black bullhead Ameiurus melas with comments on its invasive potential. J. Appl. Ichtyol. 25, 79-84.

Oksanen, J., Blanchet, F.G., Kindt, R., Legendre, P., Minchin, P.R., O’Hara, R.B., Simpson, G.L., Solymos, P., Stevens, H.H., Wagner, H., 2013. Vegan: Community Ecology Package. R package Version 2. 0-9, 〈http://CRAN.R-project.org/package=vegan $\rangle$.

Paulovits, G., Tátrai, I., Bíró, P., Perényi, I., Lakatos, Gy., 1994. Fish stock structure in the littoral zone of Lake Balaton. Verh. Int. Verein Limnol. 25, 2162-2163.

Paulovits, G., Ferincz, Á., Staszny, Á., Weiperth, A., Tátrai, I., Korponai, J., Mátyás, K., Kováts, N., 2014. Long-term changes in the fish assemblage structure of a shallow eutrophic reservoir (Lake Hídvégi Hungary), with special reference to the exotic Carassius gibelio. Int. Rev. Hydrobiol. 99, 373-381.

R Development Core Team, 2013. R: A Language and Environment for Statistical Computing. R Foundation for Statistical Computing, Vienna, Austria, 〈http://www.R-project.org (January 2014).
Rieman, B., Clayton, J., 1997. Wildlife and native fish: issues of forest health and conservation of sensitive species. Fisheries 22, 6-15.

Rylková, K., Kalous, L., Bohlen, J., Lamatsch, D.K., Petrtýl, M., 2013. Phylogeny and biogeographic history of the cyprinid fish genus Carassius (Teleostei: Cyprinidae) with focus on natural and anthropogenic arrivals in Europe. Aquaculture 380 13-20.

Sály, P., Takács, P., Kiss, I., Bíró, P., Erős, T., 2011. The relative influence of spatial context and catchment- and site-scale environmental factors on stream fish assemblages in a human-modified landscape. Ecol. Freshw. Fish 20, 251-262.

Schlosser, I.J., 1998. Fish recruitment, dispersal, and trophic interactions in a het erogeneous lotic environment. Oecologia 113, 260-268.

Shea, K., Chesson, P., 2002. Community ecology theory as a framework for biologica invasions. Trends Ecol. Evol. 17, 170-176.

Simberloff, D., 2002. Today Tiritiri Matangi, tomorrow the World! Are we aiming too low in invasives control? In: Veitch, C.R., Clout, M.N. (Eds.), Turning the Tide: The Eradication of Invasive Species. IUCN, Gland, Switzerland and Cambridge, UK, pp. 4-13.

Specziár, A., Erős, T., György, Á.I., Tátrai, I., Bíró, P., 2009. A comparison between the benthic Nordic gillnet and whole water column gillnet for characterizing fish assemblages in the shallow Lake Balaton. Annal. Limnol.-Int. J. Limnol. 45 $171-180$.

Specziár, A., Takács, P., Czeglédi, I., Erös, T., 2012. The role of the electrofishing equipment type and the operator in assessing fish assemblages in a non-wadeable lowland river. Fish. Res. 125-126, 99-107.

Szalay, M., 1954. Új halfaj Magyarországon-ezüstkárász, Halászat, 1, 4 (in Hungarian).

Tarkan, A.S., Copp, G.H., Top, N., Özdemir, N., Önsoy, B., Bilge, G., Filiz, H., Yapici, H., Ekmekci, F.G., Kirankaya, S.G., Emiroglu, Ö., Gaygusuz, Ö., Gürsoy Galgusuz, C., Oymak, A., Özcan, G., Sac, G., 2012a. Are introduced gibel carp Carassius gibelio in Turkey more invasive in artificial than in natural waters? Fish. Manage. Ecol. 19, 178-187.

Tarkan, A.S., Gaygusuz, Ö., Gürsoy-Gaygusuz, C., Sac, G., Copp, G.H., 2012b. Circumstantial evidence of gibel carp Carassius gibelio reproductive competition exerted on native fish species in a mesotrophic reservoir. Fish. Manage. Ecol. 19 167-177.

Vila-Gispert, A., Alcaraz, C., Garcia-Berthou, E., 2005. Life-history traits of invasive fish in small Mediterranean streams. Biol. Invasions 7, 107-116.

VKKI, 2010. Vízgyűjtő-gazdálkodási terv-Balaton részvízgyủjtő. In: Vízügyi és Környezetvédelmi Központi Igazgatóság (160 pp.; in Hungarian).

Woodford, D.J., McIntosh, A.R., 2010. Evidence of source-sink metapopulations in a vulnerable native galaxiid fish driven by introduced trout. Ecol. Appl. 20, 967-977.

Zlinszky, A., Tímár, G., 2013. Historic maps as a data source for socio-hydrology: a case study of the Lake Balaton wetland system, Hungary. Hydrol. Earth Syst. Sci. $17,4589-4606$. 